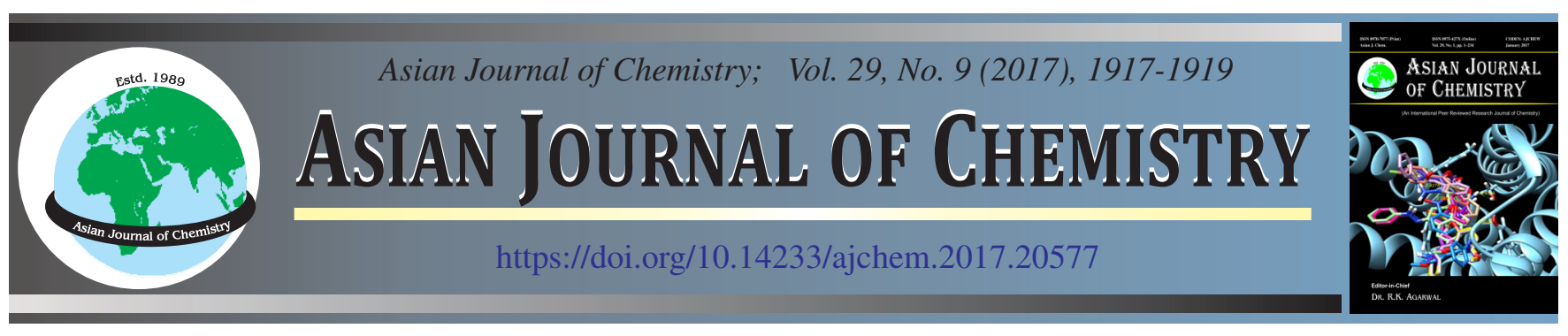

\title{
Spectrophotometric Evaluation of Trace level Chromium in Alloy Steel
}

\author{
B.L. Bhaskar ${ }^{*}$, S. Anil Kumar and T.M. Mohan Kumar
}

Department of Chemistry, Amrita School of Engineering, Bengaluru Campus, Amrita Vishwa Vidyapeetham, Amrita University, Bengaluru-560 035, India

*Corresponding author: Fax: +91 80 28440092; Tel: +91 80 25183700; E-mail: basee77@ gmail.com

Received: 9 February 2017;

Accepted: 26 April 2017;

Published online: 30 June 2017;

AJC-18465

\begin{abstract}
A facile and highly responsive spectrophotometric method for the quantification of ultra-trace quantities of chromium(VI) is described. The proposed method is derived from the oxidation of iminodibenzyl (IDB) with chromium in strong acid medium to get a blue coloured product, having $\lambda_{\max }$ at $690 \mathrm{~nm}$. Stability of the colour developed is found to be around $48 \mathrm{~h}$ at room temperature. Beer's law range is observed between $0.02-0.35 \mu \mathrm{g} \mathrm{mL} \mathrm{m}^{-1}$ of chromium concentration. The coefficients of molar absorptivity and Sandell's sensitivity are found to be $1.03 \times 10^{5} \mathrm{~L} \mathrm{~mol}^{-1} \mathrm{~cm}^{-1}$ and $0.000523 \mu \mathrm{g} \mathrm{cm}^{-2}$, respectively where as the detection limit is $0.9 \mathrm{ng} \mathrm{mL}$. The method has been optimized for reaction conditions and optical parameters. Tolerance limits for various interfering ions were studied. The efficiency of the method was shown by successful determination of traces of chromium in alloy steel samples.

Keywords: Iminodibenzyl, Alloy steel, Chromium(VI), Spectrophotometry.
\end{abstract}

\section{INTRODUCTION}

Chromium finds application in metallurgical industry as alloying agent in steels to increase temper, hardness and resistance to corrosion [1]. Many techniques have been reported for estimating chromium at low concentration that includes titrimetry [2], complexometry [3], AAS [4], IR [5], amplification method [6], radiochemical method [7], NAA [8], ICP-MS [9], ICP-AES [10], electro-analytical methods such as potentiometry [11], amperometry [12], coulometry [13], polarography [14] and spectrophotometry.

Existing spectrophotometric methods that use oxidation of organic compounds $[15,16]$ or development of ionic associates [17] suffer from elevated blank values. The most common reagent used in spectroscopy is diphenyl carbazide [18], but not without hindrances from interfering ions such as $\mathrm{Fe}^{3+}, \mathrm{Mo}^{6+}$, $\mathrm{Cu}^{2+}$ and $\mathrm{Hg}^{2+}$. In addition, the developed complex becomes unstable beyond $30 \mathrm{~min}$. The other coupling agents studied such as (2-pyridylazo)resorcinol, phenyl arsenazo, gallacetophenone oxime, citrazinic acid, etc. are undesirable as they are either carcinogens, less sensitive and/or tedious methods. In this article, a new heterocyclic organic compound iminodibenzyl has been proposed for the assaying of chromium in alloy steel samples.

\section{EXPERIMENTAL}

Systronics make Spectrophotometer (model No. 106) with $10 \mathrm{~mm}$ calibrated quartz cell was used for scanning. $\mathrm{Cr}(\mathrm{VI})$ stock solution $\left(1000 \mu \mathrm{g} \mathrm{mL}^{-1}\right)$ was made by dissolving 0.2828 g potassium dichromate (Merck, Germany) in deionized distilled water and diluted to $100 \mathrm{~mL}$. The working standard was made by suitable dilution.

Procedure: Aliquot containing $0.02-0.35 \mu \mathrm{g} / \mathrm{mL}$ equivalent of $\mathrm{Cr}(\mathrm{VI})$ was taken into a sequence of $10 \mathrm{~mL}$ volumetric flasks and $1 \mathrm{~mL}$ of iminodibenzyl $(0.1 \% \mathrm{w} / \mathrm{v}$ in ethanol) was added. The solution was left for about 5 min to complete the reaction and diluted to $10 \mathrm{~mL}$ using $10 \mathrm{M}$ sulphuric acid. The highest colour intensity was observed after $5 \mathrm{~min}$ and the same was found to be stable up to $48 \mathrm{~h}$. The absorbance was measured at $690 \mathrm{~nm}$ against the equivalent reagent blank and a calibration graph was plotted.

Sample preparation: About $1 \mathrm{~g}$ of sample alloy steel was weighed and dissolved in $10 \mathrm{~mL}$ of conc. $\mathrm{HCl}$, followed by the drop wise addition of about $3 \mathrm{~mL}$ conc. nitric acid to assist the dissolution. When the vigorous reaction was completed, the solution was digested with gentle heating for about 15 min. The solution was then cooled and diluted to $100 \mathrm{~mL}$, filtered through a Whatmann No. 541 filter paper, washed the residue on the filter paper with 1:20 hot $\mathrm{HCl}$ and washings were collected. $3-5 \mathrm{~mL}$ of $10 \%$ (w/v) sodium hydroxide was added to precipitate $\mathrm{Fe}^{2+}, \mathrm{Cu}^{2+}, \mathrm{Co}^{2+}$ as their hydroxides and filtered the precipitate. This was then diluted to $250 \mathrm{~mL}$ and mixed thoroughly. $0.5 \mathrm{~mL}$ of the stock was then diluted to $100 \mathrm{~mL}$ in a calibration flask and $1 \mathrm{~mL}$ of the diluted stock was analyzed by the recommended procedure. 


\section{RESULTS AND DISCUSSION}

Preliminary experiments showed that iminodibenzyl do not form any coloured species in hydrochloric acid or in acetic acid medium. Though, iminodibenzyl was found to form blue coloured species with $\mathrm{Cr}(\mathrm{VI})$ in both sulphuric acid and phosphoric acid medium at ambient temperature, the colour sensitivity in the latter is very low. Therefore, sulphuric acid medium was selected for further studies. The common interfering ions such as $\mathrm{Fe}^{2+}, \mathrm{Cu}^{2+}, \mathrm{Co}^{2+}, \mathrm{Mn}^{2+}$, etc. can be removed as their respective hydroxides with sodium hydroxide. The blue colour was deemed to be due to a radical cation.

Spectral characteristics of coloured product: Blue coloured product is formed by the reaction between $\mathrm{Cr}(\mathrm{VI})$ and iminodibenzyl in sulphuric acid medium. The absorption spectrum was obtained by scanning between $400-800 \mathrm{~nm}$ with respect to reagent blank. The value of $\lambda_{\max }$ was found to be $690 \mathrm{~nm}$ as shown in Fig. 1. The optical properties and precision studies are given in Table-1.

TABLE-1

OPTICAL PROPERTIES OF THE COLOURED PRODUCT

\begin{tabular}{|c|c|}
\hline Parameter & Iminodibenzyl system \\
\hline Colour & Blue \\
\hline$\lambda_{\max }(\mathrm{nm})$ & 690 \\
\hline Stability (h) & 48 \\
\hline Beer's law range $\left(\mu \mathrm{g} \mathrm{mL}^{-1}\right)$ & $0.02-0.35$ \\
\hline Molar absorptivity $\left(\mathrm{L} \mathrm{mol}^{-1} \mathrm{~cm}^{-1}\right)$ & $1.03 \times 10^{5}$ \\
\hline Sandell's Sensitivity $\left(\mu \mathrm{g} \mathrm{cm}^{-2}\right)$ & 0.000523 \\
\hline \multicolumn{2}{|l|}{ Regression equation $(\mathrm{Y})^{\mathrm{a}}$} \\
\hline Slope (a) & 1.988 \\
\hline Intercept (b) & 0.0098 \\
\hline Correlation co-efficient & 0.9999 \\
\hline Relative standard deviation ${ }^{*}$ & 0.1547 \\
\hline Range of error ( $95 \%$ confidence level) & \pm 0.0029 \\
\hline Detection limit $\left(\mathrm{ng} \mathrm{mL}^{-1}\right)$ & 0.9 \\
\hline
\end{tabular}

The precision of the proposed method was verified by considering actual determination of $\lambda_{\max }$ of five replicate samples having same amount of $\mathrm{Cr}(\mathrm{VI})$. The percentage of relative standard deviation was calculated and is presented in Table-1. The extent of accuracy was evaluated by analyzing different quantities of chromium within the Beer's law range.

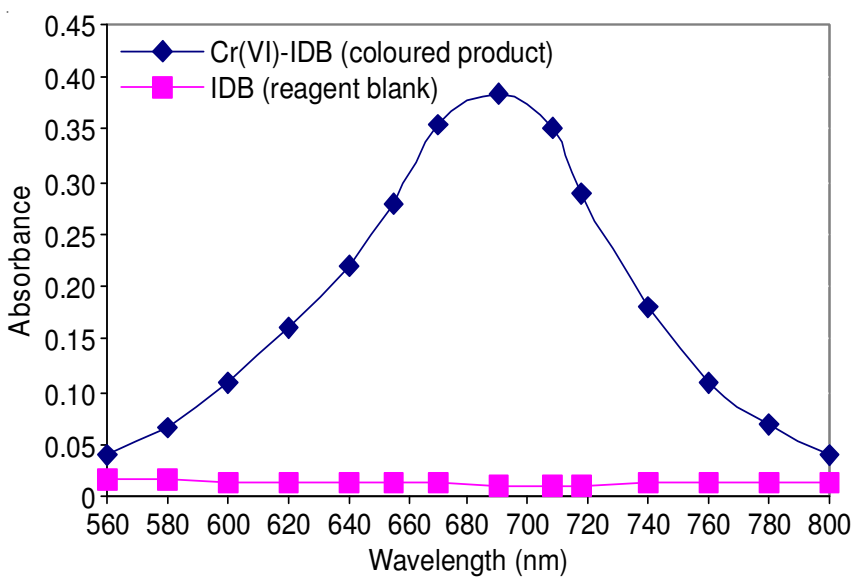

Fig. 1. Absorption spectrum: coloured product vs. reagent blank
Effect of iminodibenzyl concentration: This has been evaluated by adding different amounts of iminodibenzyl to $0.2 \mu \mathrm{g} \mathrm{mL} \mathrm{m}^{-1}$ chromium and then observing the absorbance. The optimal amount of iminodibenzyl for maximum was fixed at $1 \mathrm{~mL}$ at $690 \mathrm{~nm}$. The addition of excess iminodibenzyl leads to the decrease in colour intensity, but higher concentration of iminodibenzyl above $0.01 \%$ develops green colour in sulphuric acid medium probably due to reduction of $\mathrm{Cr}(\mathrm{VI})$ to $\mathrm{Cr}(\mathrm{III})$. Hence, $1 \mathrm{~mL}$ of $0.01 \%$ iminodibenzyl was used in final volume of $10 \mathrm{~mL}$ for $0.2 \mu \mathrm{g} \mathrm{mL} \mathrm{m}^{-1}$ of $\mathrm{Cr}(\mathrm{VI})$.

Colour stability: No appreciable changes were noted in $\lambda_{\max }$ when the temperature is varied between 10 and $80{ }^{\circ} \mathrm{C}$. As stated earlier, the colour was found to be steady for $48 \mathrm{~h}$, however maximum and stable absorbance was achieved after 5 min.

Analytical characteristics: $\lambda_{\max }$ of the coloured product over varying concentration of chromium was tabulated. The calibration graph appears straight line between 0.02-0.35 $\mu \mathrm{g}$ $\mathrm{mL}^{-1}$ of chromium. These measurements were carried out with respect to corresponding reagent blank.

The molar absorptivity at $690 \mathrm{~nm}$ was $1.03 \times 10^{5} \mathrm{~L} \mathrm{~mol}^{-1}$ $\mathrm{cm}^{-1}$. Beer's law range, Sandell's sensitivity and other analytical properties were evaluated. The ideal concentration range for optimal spectrophotometric measurement, as evaluated by Ringbom plot was $0.03-0.3 \mu \mathrm{g} \mathrm{mL} \mathrm{m}^{-1}$ of $\mathrm{Cr}(\mathrm{VI})$. Ionic nature of $\mathrm{Cr}(\mathrm{VI})$-iminodibenzyl species in sulphuric aid medium was determined by ion exchange experiment. When $10 \mathrm{~mL}$ of solution of blue $\mathrm{Cr}(\mathrm{VI})$-iminodibenzyl species in sulphuric acid medium was passed through DOWEX $50 \mathrm{~W}$-X8 anion exchange column $(26 \times 11.5 \mathrm{~cm})$, the blue colour was completely absorbed and the evaluate was colourless, indicating the $\mathrm{Cr}(\mathrm{VI})-$ iminodibenzyl coloured species in sulphuric acid medium is cationic in nature.

Effect of foreign ions: The interference from common excipient ions in stainless steel was evaluated to study their impact in the proposed method. This was done by introducing definite amounts of each ion to a fixed chromium concentration and analyzing spectrophotometrically. The tolerance limit is ideally considered as the amount of foreign substances which can cause an error of $2 \%$ in optical density (Table-2). Interestingly, metal ions such as $\mathrm{Fe}^{2+}, \mathrm{Fe}^{3+}, \mathrm{Mn}^{2+}, \mathrm{Cu}^{2+}$, etc. which interfered strongly with most of the other reported methods showed no interference.

\section{Conclusion}

The reported method has been validated by applying the same on stainless steel variants for evaluating concentration

\begin{tabular}{|c|c|}
\hline \multicolumn{2}{|l|}{$\begin{array}{c}\text { TABLE-2 } \\
\text { EFFECT OF EXCIPENTS }\end{array}$} \\
\hline Foreign ion & $\begin{array}{c}\text { Tolerance } \\
\text { limit }\left(\mu \mathrm{g} \mathrm{mL} \mathrm{mL}^{-1)}\right.\end{array}$ \\
\hline EDTA & 2000 \\
\hline${ }^{\mathrm{a}} \mathrm{Mn}^{2+}$ & 800 \\
\hline $\mathrm{Cd}^{2+}, \mathrm{Mg}^{2+}, \mathrm{Cl}^{-},{ }^{\mathrm{a}} \mathrm{Cu}^{2+},{ }^{\mathrm{a}} \mathrm{Co}^{2+},{ }^{\mathrm{a}} \mathrm{Fe}^{2+}$, Sulphamic acid & 400 \\
\hline $\mathrm{Na}^{+}, \mathrm{K}^{+}, \mathrm{Hg}^{2+}, \mathrm{Zn}^{2+}$, perchlorate & 250 \\
\hline $\mathrm{Al}^{3+}, \mathrm{CO}_{3}^{2-}$, Acetate, Tartarate & 200 \\
\hline${ }^{\mathrm{b}} \mathrm{Ca}^{2+}$ & 100 \\
\hline $\mathrm{NO}_{2}^{-}, \mathrm{Ni}^{2+}$ & 50 \\
\hline
\end{tabular}




\begin{tabular}{|c|c|c|c|c|c|}
\hline \multicolumn{6}{|c|}{$\begin{array}{c}\text { TABLE-4 } \\
\text { COMPARATIVE STUDY WITH REPORTED METHODS }\end{array}$} \\
\hline Reagent & $\begin{array}{l}\lambda_{\max } \\
(\mathrm{nm})\end{array}$ & $\begin{array}{l}\text { Range } \\
\left(\mu \mathrm{g} \mathrm{mL} L^{-1}\right)\end{array}$ & $\begin{array}{l}\text { Mo lar absorptivity } \\
\left(\mathrm{L} \mathrm{mol}^{-1} \mathrm{~cm}^{-1}\right)\end{array}$ & Remarks & Ref. \\
\hline $\begin{array}{l}\text { 3-(2-Pyridyl)-5,6-bis (5-(2-furyl disulfonic } \\
\text { acid)-1,2,4-triazine disodiu m salt }\end{array}$ & 593 & $1-40$ & $3.5 \times 10^{4}$ & $\begin{array}{l}\text { Less sensitive, Interference from } \\
\mathrm{CN}^{-}, \mathrm{NO}_{2} \text {, EDTA and citrates }\end{array}$ & [19] \\
\hline Sulphanilamide-Saccharin & 390 & - & $2.63 \times 10^{4}$ & Complicated reaction involving & [20] \\
\hline$p$-Nitroaniline-Saccharin & 372 & - & $5.40 \times 10^{4}$ & diazotization at $4{ }^{\circ} \mathrm{C}$ & [20] \\
\hline 4-(2-Thiazolylazo)resocinol & 545 & - & $2.73 \times 10^{4}$ & Microw ave conditions required & [21] \\
\hline Cyclam & 379 & - & $1.60 \times 10^{4}$ & pH dependent & [22] \\
\hline Variamine blue & 556 & $2-12$ & $9.11 \times 10^{3}$ & Less sensitive, $\mathrm{pH}$ dependent & {$[23]$} \\
\hline Iminodibenzyl & 690 & $0.02-0.35$ & $1.03 \times 10^{5}$ & Simple \& sensitive & $\begin{array}{c}\text { Proposed } \\
\text { method }\end{array}$ \\
\hline
\end{tabular}

of chromium and the results are tabulated in Table-3. Iminodibenzyl appears to be a better choice as coupling agent for spectrophotometric study as evidenced by the comparative study given in Table-4. Further, recovery studies testify that the proposed method can be used successfully for the determination of chromium in steel alloys.

TABLE-3

DETERMINATION OF CHROMIUM IN STAINLESS STEEL

\begin{tabular}{lccc}
\multicolumn{1}{c}{ Samples } & $\begin{array}{c}\text { Cr } \\
(\%)\end{array}$ & Amount & $\begin{array}{c}\text { Recovery } \\
(\%)\end{array}$ \\
\hline $\begin{array}{l}\text { GKW Steel, India }(0.05 \mathrm{~g} / 100 \mathrm{~mL}) ; \\
\text { C 0.54, Mn 0.89, S 0.008, P 0.034, }\end{array}$ & 1.02 & 1.018 & 99.7 \\
Si 0.033, V 0.13 & & & \\
$\begin{array}{l}\text { Stainless steel no. 394 (0.05 g/100 } \\
\text { mL); Ni 8.12, Fe 70-71 }\end{array}$ & 18.0 & 18.08 & 101.2 \\
Ferrochrome Cr 65, Fe 35 & 65.0 & 64.89 & 99.8 \\
\hline
\end{tabular}

\section{REFERENCES}

1. K. Othmer, Encyclopedia of Chemical Technology, John Wiley \& Sons, New York (1981).

2. A. D' Sousa, Chem. Anal., 50, 9 (1961).

3. L. Erdey and I. Kasa, Talanta, 10, 1273 (1963); https://doi.org/10.1016/0039-9140(63)80187-3.

4. A. Gaspar, C. Sogor and J. Posta, Fresenius J. Anal. Chem., 363, 480 (1999);

https://doi.org/10.1007/s002160051228.

5. F.R. Haba and C.L. Wilson, Talanta, 9, 841 (1962); https://doi.org/10.1016/0039-9140(62)80192-1.

6. H. Wesiz and M. Gönner, Anal. Chim. Acta, 43, 235 (1968); https://doi.org/10.1016/S0003-2670(00)89212-0.

7. I. Kuzelewska, H. Polkowska-Motrenko and B. Danko, J. Radioanal. Nucl. Chem., 310, 559 (2016);

https://doi.org/10.1007/s10967-016-4896-0.
8. C. Schnabel, U. Herpers and R. Michel, J. Radioanal. Nucl. Chem., 178, 19 (1994); https://doi.org/10.1007/BF02068653.

9. H. Gürleyük and D. Wallschläger, J. Anal. At. Spectrom., 16, 926 (2001); https://doi.org/10.1039/B102740A.

10. S. Balasubramanian and V. Puglenthi, Talanta, 50, 457 (1999); https://doi.org/10.1016/S0039-9140(99)00135-6.

11. L. Erdey, G. Svehla and O. Weber, Z. Anal. Chem., 240, 91 (1968); https://doi.org/10.1007/BF00531155.

12. H.J. Keily, A. Eldridge and J.O. Hibbits, Anal. Chim. Acta, 21, 135 (1959); https://doi.org/10.1016/0003-2670(59)80153-7.

13. J. Knoeck and H. Diehl, Talanta, 16, 181 (1969); https://doi.org/10.1016/0039-9140(69)80269-9.

14. J.J. Lingane and I.M. Kolthoff, J. Am. Chem. Soc., 62, 852 (1940); https://doi.org/10.1021/ja01861a040.

15. F. Buscarons and J. Artigas, Anal. Chim. Acta, 16, 452 (1957); https://doi.org/10.1016/S0003-2670(00)89966-3.

16. J.B. Raj and H.S. Gowda, Analyst, 120, 1815 (1995); https://doi.org/10.1039/an9952001815.

17. M. Kamburova, Talanta, 40, 707 (1993); https://doi.org/10.1016/0039-9140(93)80283-W.

18. H. Marchart, Anal. Chim. Acta, 30, 11 (1964); https://doi.org/10.1016/S0003-2670(00)88678-X.

19. M.C. Mehra, B. Francoeur and M. Satake, Mikrochim. Acta, 84, 61 (1984); https://doi.org/10.1007/BF01204157.

20. T. Cherian and B. Narayana, Indian J. Chem. Technol., 12, 596 (2005).

21. L.S. Carvalho, A.C.S. Costa, S.L.C. Ferreira and L.S.G. Teixeira, J. Braz. Chem. Soc., 15, 153 (2004); https://doi.org/10.1590/S0103-50532004000100025.

22. M.A. Zaitoun, Int. J. Environ. Anal. Chem., 85, 399 (2005); https://doi.org/10.1080/03067310500075913.

23. B. Narayana and T. Cherian, J. Braz. Chem. Soc., 16, 197 (2005); https://doi.org/10.1590/S0103-50532005000200011. 